\title{
Growth-inhibitory effects of a B-glucan from the mycelium of Poria cocos on human breast carcinoma MCF-7 cells: Cell-cycle arrest and apoptosis induction
}

\author{
MEI ZHANG, LAWRENCE C.-M. CHIU, PETER C.K. CHEUNG and VINCENT E.C. OOI \\ Department of Biology, The Chinese University of Hong Kong, Shatin, New Territories, Hong Kong, P.R. China
}

Received August 16, 2005; Accepted October 14, 2005

\begin{abstract}
Because of the reported immune-enhancing and antitumor activities of some mushroom polysaccharides, their applications as biological response modifiers have attracted significant attention. We have purified a water-soluble $\beta$-glucan PCM3-II, comprising mainly $1 \rightarrow 3$ and $1 \rightarrow 4$ linkages, from the mycelia of Poria cocos (Schw.) Wolf (Fu-ling). In this study, the growth-inhibitory effect of PCM3-II was further explored on the human breast carcinoma MCF-7 cells in vitro. The dose effect of PCM3-II was studied by incubating the breast cancer cells with $12.5-400 \mu \mathrm{g} / \mathrm{ml}$ of the glucan for $72 \mathrm{~h}$. The MTT study showed that PCM3-II reduced proliferation and viability of the MCF-7 cells dose-dependently, so that the cancer-cell growth was decreased by $50 \%$ of the control level at $400 \mu \mathrm{g} / \mathrm{ml}$ of the glucan. The time effect of PCM3-II was then investigated by treating the breast cancer cells with $400 \mu \mathrm{g} / \mathrm{ml}$ of the glucan for 24,48 and $72 \mathrm{~h}$, respectively. Results from the flow cytometry study demonstrated that PCM3-II induced cell-cycle $\mathrm{G}_{1}$ arrest time-dependently and about $90 \%$ of the cells in cell cycle were accumulated at $\mathrm{G}_{1}$ phase after $72 \mathrm{~h}$ of treatment. The $\mathrm{G}_{1}$ arrest was associated with downregulations of the unscheduled cyclin D1 and cyclin E expressions in the breast cancer cells. Apoptosis was also induced by PCM3-II in the MCF-7 cells, so that the subG $_{1}$ cells in DNA histogram of the flow cytometry were elevated by 5 -fold of the control level at $48 \mathrm{~h}$ and by 24 -fold at $72 \mathrm{~h}$ of treatment. The immunoblot study also showed that the glucan induced depletion of the antiapoptotic Bcl-2 protein, but not the proapoptotic Bax protein, so that the $\mathrm{Bax} / \mathrm{Bcl}-2$ ratio was elevated in the breast cancer cells at the time when the most prominent apoptosis was also observed. In conclusion, although the detailed mechanism for the antitumor activity of the $P$. $\operatorname{cocos} \beta$-glucan still needs further
\end{abstract}

Correspondence to: Dr Lawrence C.-M. Chiu, Natural Product Research Laboratory, Department of Biology, The Chinese University of Hong Kong, Shatin, NT, Hong Kong, P.R. China

E-mail address: chimingchiu@graduate.hku.hk

Key words: Poria cocos, B-glucan, MCF-7, cell cycle, apoptosis investigation, this study provides preliminary insights into its mode of action and perspectives of its development as a water-soluble anti-tumor agent.

\section{Introduction}

Poria cocos (Schw.) Wolf (Fu-ling) has been used as an important medicinal herb in China and some Asian countries, particularly Japan and Korea, for its diuretic and antidepressant activities. Results from the recent experimental studies further supported application of the chemical constituents from $P$. cocos, especially triterpenes and polysaccharides, as novel anticancer agents. The triterpenes, namely poricoic acids, tumulosic acids, polyporenic acid, and dehydroabietic acid inhibit the tumor-promoting activity of 12-O-tetradecanoylphorbol-13-acetate (TPA); poricoic acid and tumulosic acid, on the other hand, exhibit cytotoxicity on a number of human cancer cells in vitro (1). Dehydroebriconic acid, a selective topoisomerase II inhibitor, prevents the growth of human gastric cancer cells by inducing the cellcycle $\mathrm{G}_{1}$ arrest (2). Pachymic acid reduces the proliferation of and induces apoptosis in both the androgen-insensitive DU145 and androgen-responsive LNCaP prostate cancer cells, with decrease in expression and activation of the proteins in the AKT cell survival pathway (3). Although the knowledge on the $P$. cocos polysaccharides is relatively limited comparing to that on its triterpenes, application of the polysaccharides as antitumor agent has attracted significant attention in recent years (4). A neutral polysaccharide fraction from $P$. cocos was found to exhibit growth-inhibitory and differentiation-inducing activities on the human leukemic U937 and HL-60 cells, mainly due to the elevated IFN- $\gamma$ and TNF- $\alpha$ expressions (5). We also purified two alkali-soluble polysaccharides, namely PCM3-I and PCM3-II, from the $P$. cocos mycelia; structural elucidation with infrared (IR), gas chromatography (GC), and carbon-13 nuclear magnetic resonance (NMR) spectroscopy revealed that PCM3-I is a water-insoluble $\alpha$-heteropolysaccharide, consisting of xylose, mannose, and glucose, and PCM3-II, on the other hand, is a $ß$-type polysaccharide, comprising mainly glucose $(98.9 \%$ in the total carbohydrate content) and has a very good water solubility (6). These polysaccharides inhibited the proliferation of and exhibited cytotoxic effect on human leukemic HL-60 cells in vitro and retarded growth of the mouse sarcoma S-180 
in BALB/c mice in vivo (6). However, their growth-inhibitory effects have not yet been evaluated on cancers of other histotypes and the antitumor mechanisms are not known.

Breast cancer is a complex disease with a significant number of genetic and environmental risk factors associated with an increased occurrence (7) and is the most malignant disease in women (8). The growth-inhibitory effect of PCM3-II on the human breast carcinoma MCF-7 cells was explored in the present study. MCF-7, which is one of the cell lines commonly used for breast cancer research, coexpresses both the insulin-like growth factor 1 receptor (IGF$1 \mathrm{R})$ and the estrogen receptor (ER), so that the two signaling systems are engaged in a crosstalk that leads to synergistic growth (9). The present results showed that PCM3-II retarded growth of the breast cancer cells, mediated by both cell-cycle arrest and apoptosis induction. The arrest of cellcycle progression was associated with depletions of cyclin D1 and cyclin E expressions, while apoptosis was associated with elevation of the proapoptotic $\mathrm{Bax} / \mathrm{Bcl}-2$ ratio. This investigation focused on the mechanisms for the antiproliferative and cytotoxic effects of PCM3-II, which would have great significance in its development as a novel and water-soluble antitumor agent.

\section{Materials and methods}

PCM3-II, antibodies, and chemicals. PCM3-II, which is a water-soluble B-glucan, was purified from the mycelia of $P$. cocos, according to the procedures described in our previous study (6). Mouse anti-human cyclin D1 (clone G124-326) and cyclin E (clone HE12) antibodies, and fluorescein isothiocyanate (FITC)-conjugated goat anti-mouse Ig specific polyclonal antibody (multiple adsorption) were purchased from BD Pharmingen, San Jose, CA. Mouse anti-human bcl-2 (clone Bcl-2/100) and bax (clone 6A7) antibodies were provided by BD Transduction Laboratories, San Jose, CA. Alkaline phosphatase (AP)-conjugated goat anti-mouse Ig specific polyclonal antibody was obtained from Bio-Rad, Hercules, CA. Unless otherwise stated, all the other chemicals were obtained from Sigma, St. Louis, MO.

Cell culture and in vitro proliferation and cytotoxicity assay. Human breast carcinoma MCF-7 cells were obtained from the American Type Culture Collection (ATCC), Manassas, VA. The cells were grown in RPMI-1640 medium, supplemented with $10 \% \mathrm{FBS}$, and incubated at fully humidified atmosphere of $95 \%$ room air and $5 \% \mathrm{CO}_{2}$ at $37^{\circ} \mathrm{C}$.

The breast cancer cells were plated in 96-well microtiter plates at $2.5 \times 10^{3} /$ well, and then incubated with $12.5,25,50$, 100,200 and $400 \mu \mathrm{g} / \mathrm{ml}$ of PCM3-II respectively for $72 \mathrm{~h}$. Metabolic activity of the living cells, indicating their proliferation and viability, was determined by a previously described colorimetric method based on [4,5-dimethylthiazol2-yl]-2,5-diphenyltetrazoliumbromide (MTT) with some modifications (10). In brief, $10-\mu 1$ MTT solution $(5 \mathrm{mg} / \mathrm{ml})$ was added to each well, and the plate was then incubated for $4 \mathrm{~h}$ at $37^{\circ} \mathrm{C}$. The precipitated formazan was solubilized with $150-\mu 10.04 \mathrm{~N} \mathrm{HCl}$-isopropanol, and the absorbance was measured by a microplate reader at $570 \mathrm{~nm}$. Inhibition ratio of the cellular metabolic activity was calculated as $[(a-b) / a]$, where $a$ and $b$ are the microplate readings of the control and treatment cells, respectively.

Flow cytometric analyses of cell cycle, apoptosis, and cyclin $D 1$ and E expressions. The breast cancer cells were incubated with $400 \mu \mathrm{g} / \mathrm{ml}$ of PCM3-II for 24, 48 and $72 \mathrm{~h}$, respectively. After trypsinization, the cell pellet was collected by centrifugation, followed by washing twice with PBS and fixing in $70 \%$ ethanol at $4^{\circ} \mathrm{C}$ overnight. After the fixation, the ethanol was removed and the cells were washed with $1 \%$ bovineserum albumin (BSA) solution. The cyclin D1 or cyclin E antibody, at $10 \mu \mathrm{g} / \mathrm{ml}$, was added to the cells and incubated for $1 \mathrm{~h}$, with vortexing every $30 \mathrm{~min}$. Isotype control was also prepared with the same steps except $\mathrm{IgG}_{1}$, instead of the cyclin antibody, was used. The excess antibody was removed by washing with the BSA solution. The cells were then incubated with the FITC-conjugated secondary antibody in dark for $1 \mathrm{~h}$, with vortexing every $30 \mathrm{~min}$. The excess antibody was removed, and the cells were resuspended in $1 \mathrm{ml}$ of $500-\mu \mathrm{g} / \mathrm{ml}$ propidium iodide (PI) solution, containing $1-\mathrm{mg} / \mathrm{ml}$ RNase A. The stained cells were then analyzed by the EPICS-XL flow cytometer from Beckman Coulter, Miami, FL. The cyclin-positive cells were determined using the control software of the flow cytometer; a cell was considered as cyclin-positive if its FITC level was above the mean plus three times the standard deviation of its isotype control at the same cell-cycle phase. Apoptotic cells, because of their hypochromic subdiploid staining profile, were determined from the DNA histogram as $\mathrm{subG}_{1}$ cells, using the control software of the flow cytometer. Cells in the different cellcycle phases were measured from the DNA histogram using the Multicycle software from Phoenix Flow Systems, San Diego, CA.

Immunoblot analysis. The breast cancer cells were incubated with $400 \mu \mathrm{g} / \mathrm{ml}$ of PCM3-II for 24, 48 and $72 \mathrm{~h}$, respectively. After the treatment, lysate was prepared from $2 \times 10^{6}$ cells. The proteins in the lysate were resolved by $13 \%$ SDS-polyacrylamide gel. The resolved proteins were then transferred to a nitrocellulose membrane (Amersham Life Science, Buckinghamshire, UK). The membrane was first blocked with $0.2 \%$ Aurora ${ }^{\circledR}$ blocking reagent (ICN Biomedicals, $\mathrm{OH}$ ), followed by overnight incubation with the bcl-2 or bax antibody at $4^{\circ} \mathrm{C}$. B-actin was also measured as the loading control. The membrane was washed, and then incubated with the APconjugated secondary antibody for $1 \mathrm{~h}$, with shaking at room temperature. Color development was performed using the Immun-Blot Assay Kit (Bio-Rad). A densitometer was used to measure the relative intensity of the protein bands.

Statistical analysis. Difference in means between the control and experimental groups was compared by Student's t-test.

\section{Results}

PCM3-II reduces the proliferation and viability of MCF-7 cells. MTT assay, depending on the cellular mitochondrial dehydrogenase activity, offers a rapid and economical method for measuring cell proliferation and viability in vitro (10). In this study, the dose effect of PCM3-II on proliferation and viability 


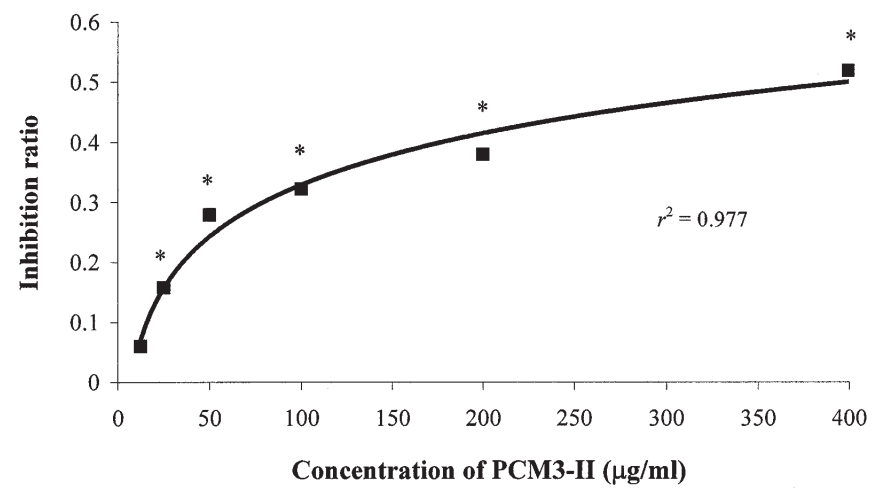

Figure 1. Effect of PCM3-II on the proliferation and viability of MCF-7 cells. The breast cancer cells were incubated with 12.5, 25, 50, 100, 200 and $400 \mu \mathrm{g} /$ $\mathrm{ml}$ of PCM3-II respectively for $72 \mathrm{~h}$. Inhibition ratio of the cellular metabolic activity was calculated as $[(a-b) / a]$, where $\mathrm{a}$ and $\mathrm{b}$ are the MTT readings of the control and treatment cells, respectively. The glucan reduced the proliferation and viability of the cancer cells dose-dependently. Results are expressed as mean of three independent replicates. ${ }^{*} \mathrm{p}<0.05$, Student's t-test.

of the human breast carcinoma MCF-7 cells were investigated using the MTT method. At $72 \mathrm{~h}$ of treatment, PCM3-II reduced the proliferation and viability of the cancer cells dosedependently, so that they were decreased by about $50 \%$ of the control level at $400 \mu \mathrm{g} / \mathrm{ml}$ of the glucan (Fig. 1).

PCM3-II induces $G_{1}$ arrest and apoptosis in the breast cancer cells. Cell cycle comprises a series of cellular events that an eukaryotic cell has to proceed orderly before it can divide into daughter cells; the rate of cell proliferation is therefore determined by the rate that the cell proceeds through the different cell-cycle phases and checkpoints (11). Results from the DNA-flow cytometry showed that $400-\mu \mathrm{g} / \mathrm{ml}$ PCM3-II did not affect cell cycle of the breast cancer cells at $24 \mathrm{~h}$ of incubation [Fig. 2(a) and (b)]. However, the glucan induced cell-cycle arrest so that the $\mathrm{G}_{1}$ cells increased from the control $45 \%$ of the cells in cell cycle to $73 \%$ at $48 \mathrm{~h}$ [Fig. 2(c) and (d)] and from $47 \%$ to $90 \%$ at $72 \mathrm{~h}$ of treatment [Fig. 2(e) and (f)]. Accompanying the elevations of $\mathrm{G}_{1}$ cells, the $\mathrm{G}_{2} / \mathrm{M}$ cells decreased from $38 \%$ to $12 \%$ at $48 \mathrm{~h}$ and from $37 \%$ to $2 \%$ at $72 \mathrm{~h}$ of incubation, while the $\mathrm{S}$ cells decreased from $17 \%$ to $13 \%$ and from $16 \%$ to $8 \%$, respectively.

Apoptosis is a mode of programmed cell death, which plays an important role in cancer chemotherapy (12). DNA fragmentation is one of the characteristic features of apoptotic cells, so that they are shown as subG ${ }_{1}$ cells in the DNA histogram of flow cytometry (13). PCM3-II was found to induce apoptosis time-dependently in the breast cancer cells. No apoptosis was induced by the glucan at $24 \mathrm{~h}$ of incubation; however, the $\mathrm{subG}_{1}$ cells elevated by 5 -fold of the control level at $48 \mathrm{~h}$ [Fig. 2(c) and (d)] and by 24-fold at $72 \mathrm{~h}$ of incubation [Fig. 2(e) and (f)].

PCM3-II downregulates cyclin D1 and cyclin E expressions in the breast cancer cells. Transitions through the different cellcycle phases and checkpoints are at least regulated by different cyclins and their dependent kinases (Cdks) (11). Since PCM3-II arrested cell cycle at $\mathrm{G}_{1}$ phase, effects of the glucan
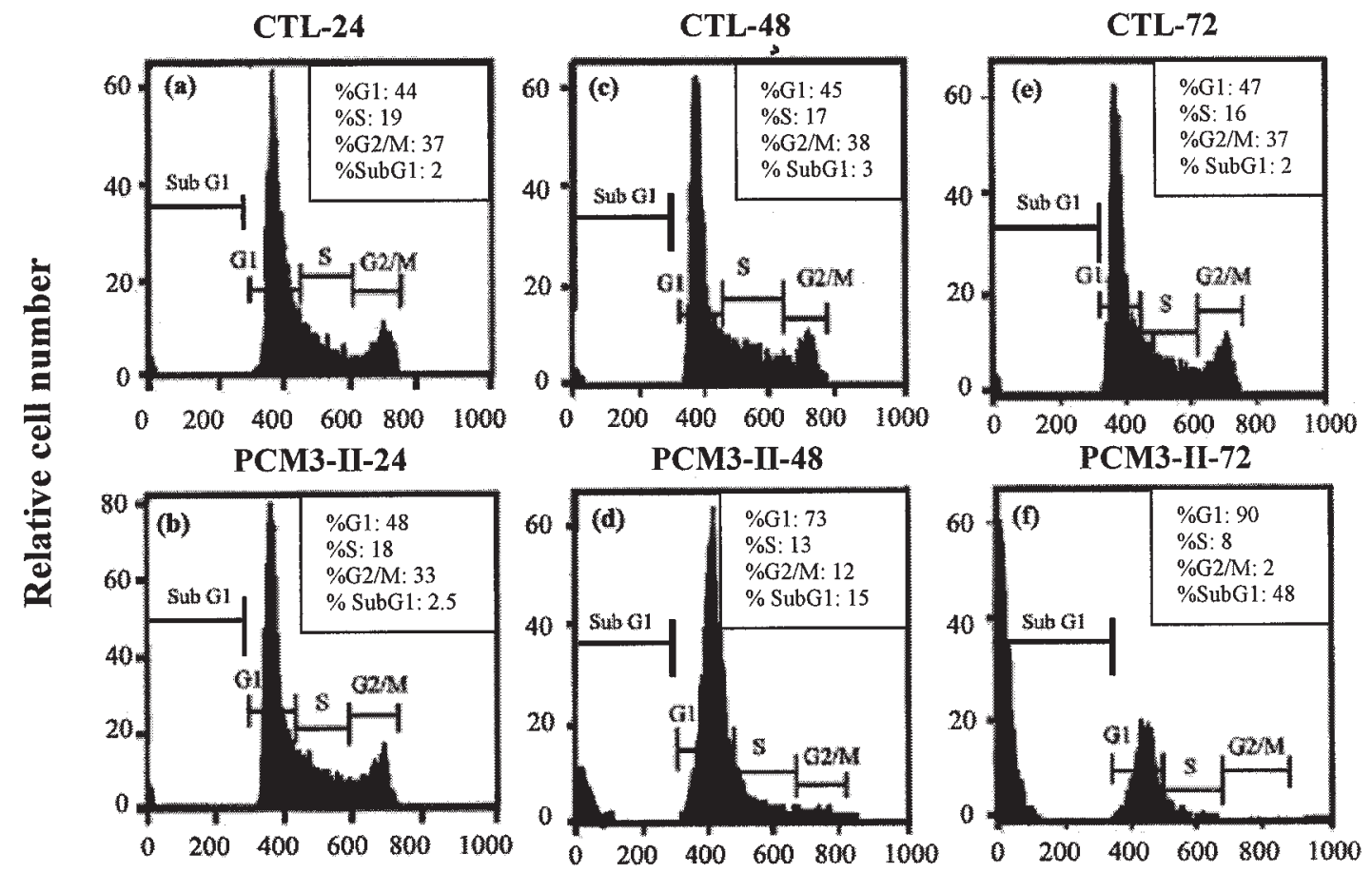

\section{PI fluorescence (DNA content)}

Figure 2. Representative DNA histograms showing the effects of PCM3-II on cell cycle and apoptosis in MCF-7 cells. The breast cancer cells were incubated with $400-\mu \mathrm{g} / \mathrm{ml} \mathrm{PCM} 3-\mathrm{II}$ for (b) $24 \mathrm{~h}$, (d) $48 \mathrm{~h}$, and (f) $72 \mathrm{~h}$ respectively, comparing to their corresponding time controls (CTL) (a, c, and e). The glucan induced $\mathrm{G}_{1}$ arrest after $48 \mathrm{~h}$ and apoptosis at $72 \mathrm{~h}$ of incubation. Numeric data showing the subG $\mathrm{G}_{1}$ cells, i.e., apoptotic cells, and the cells in different cell-cycle phases, i.e., $\mathrm{G}_{1}, \mathrm{~S}$, and $\mathrm{G}_{2} / \mathrm{M}$, are also listed. 


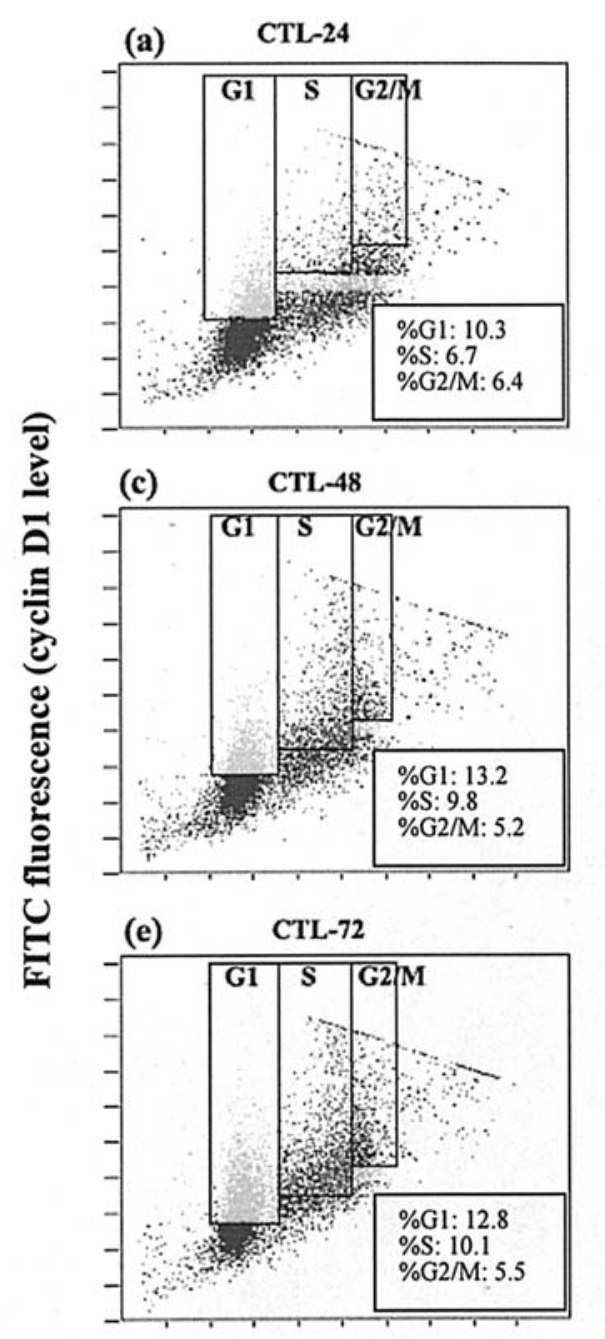

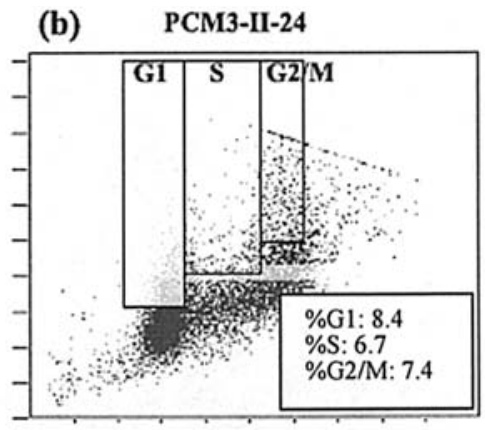
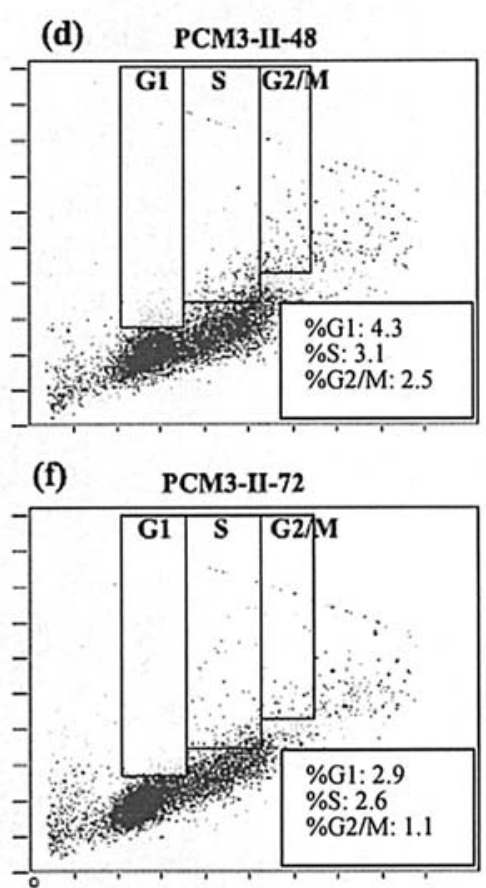

\section{PI fluorescence (DNA content)}

Figure 3. Effect of PCM3-II on the cyclin D1 expression in MCF-7 cells. The breast cancer cells were incubated with 400- $\mu \mathrm{g} / \mathrm{ml}$ PCM3-II for (b) $24 \mathrm{~h}$, (d) $48 \mathrm{~h}$, and (f) $72 \mathrm{~h}$ respectively, comparing to their corresponding time controls (CTL) (a, c and e). Cyclin D1 expression was found to be deregulated in the MCF-7 cells, so that it was found not only in $\mathrm{G}_{1}$ but also in other cell-cycle phases. PCM3-II induced downregulation of cyclin D1 expressions in all the cell-cycle phases after $48 \mathrm{~h}$ of treatment. Numeric data showing the proportion of cyclin D1-positive cells in different cell-cycle phases are also listed.

on cyclin D1, i.e., a $\mathrm{G}_{1}$ cyclin, and cyclin $\mathrm{E}$, i.e., a $\mathrm{G}_{1} / \mathrm{S}$ cyclin, were investigated. Results from the bivariate cyclin/DNA flow cytometry showed that both cyclin D1 and cyclin E expressions were deregulated in the MCF-7 cells so that they could be found in all the cell-cycle phases, instead of only $\mathrm{G}_{1}$ and $\mathrm{S}$ phases (Figs. 3 and 4). PCM3-II affected neither the cyclin D1 [Fig. 3(a) and (b)] nor cyclin E [Fig. 4(a) and (b)] expression in the breast cancer cells at $24 \mathrm{~h}$ of treatment. Interestingly, the cyclin D1-positive cells were decreased from $13.2 \%$ of $\mathrm{G}_{1}$ cells in the control group to $4.3 \%$ in the treatment group at $48 \mathrm{~h}$ [Fig. 3(c) and (d)] and from $12.8 \%$ to $2.9 \%$ at $72 \mathrm{~h}$ of incubation, with $400 \mu \mathrm{g} / \mathrm{ml}$ of the glucan [Fig. 3(e) and (f)]. Similarly, the cyclin E-positive cells were also decreased from $11.6 \%$ of $\mathrm{G}_{1}$ cells in the control group to $4.6 \%$ in the treatment group at $48 \mathrm{~h}$ [Fig. 4(c) and (d)] and from $9.4 \%$ to $1.4 \%$ at $72 \mathrm{~h}$ of treatment [Fig. 4(e) and (f)]. Both cyclin D1 and cyclin E expressions were also prominently depleted in other cell-cycle phases after $48 \mathrm{~h}$ of the PCM3-II treatment.
PCM3-II downregulates Bcl-2 expression in the breast cancer cells. Triggering and progression of the apoptosis pathways are tightly regulated by a number of gene products. Bcl-2 family proteins play a central role in the regulation of apoptosis (14). In this study, the time effects of PCM3-II on the proapoptotic Bax and antiapoptotic Bcl-2 expressions in the breast cancer cells were investigated. The glucan, at $400 \mu \mathrm{g} / \mathrm{ml}$, induced downregulation of the Bcl-2 expression after $72 \mathrm{~h}$ of treatment, while there was no significant change of the Bax expression with the different periods of incubation [Fig. 5(a)]. Elevated proapoptotic bax/bcl-2 ratio was observed at $72 \mathrm{~h}$ of treatment, when the most prominent increase of the apoptotic cells occurred [Fig. 5(b)].

\section{Discussion}

Because of their reported immune-enhancing and antitumor activities, applications of mushroom polysaccharides as biological response modifiers have attracted recent attention (4). 
(a) CTL-24

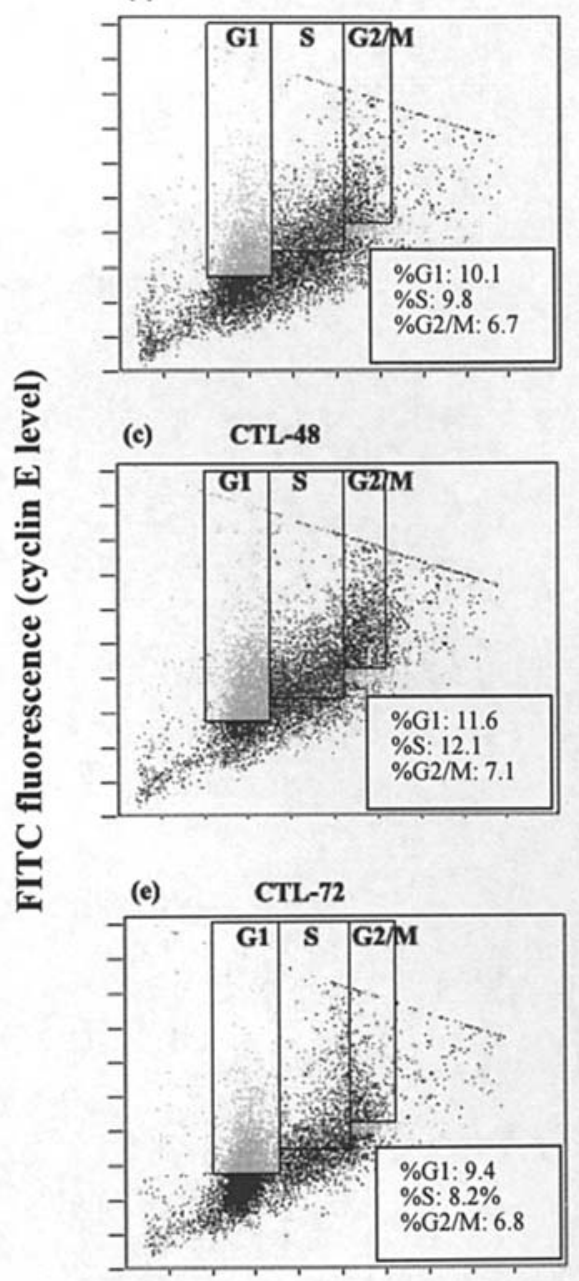

(b) PCM3-II-24

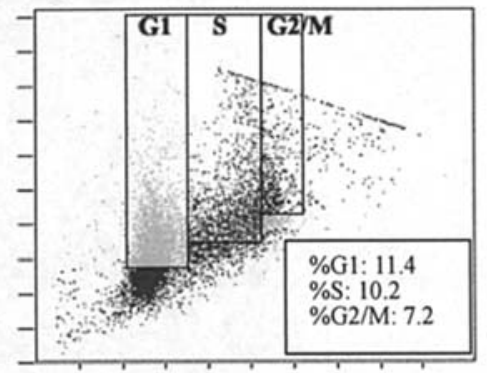

(d) PCM3-II-48

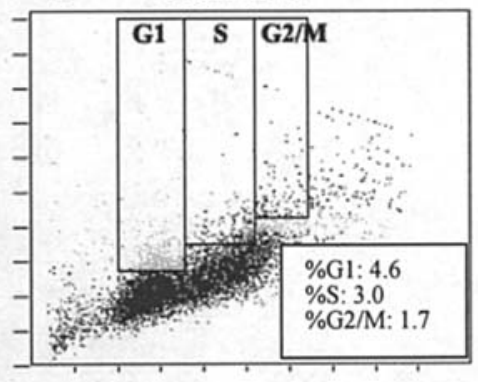

(f) PCM3-II-72

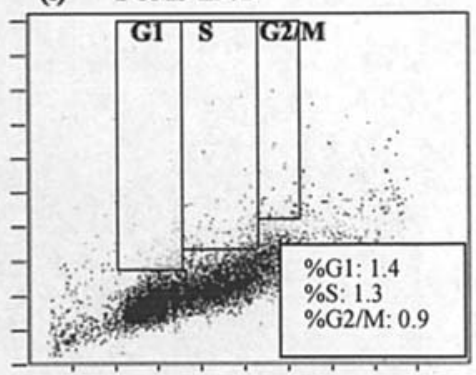

PI fluorescence (DNA content)

Figure 4. Effect of PCM3-II on the cyclin E expression in MCF-7 cells. The breast cancer cells were incubated with $400-\mu \mathrm{g} / \mathrm{ml} \mathrm{PCM} 3-\mathrm{II}$ for (b) $24 \mathrm{~h}$, (d) $48 \mathrm{~h}$ and (f) $72 \mathrm{~h}$ respectively, comparing to their corresponding time controls (CTL) (a, c and e). Cyclin E expression was found to be deregulated in the MCF-7 cells, so that it was found not only in the late $\mathrm{G}_{1}$ and early $\mathrm{S}$ but also in other cell-cycle phases. The glucan induced downregulation of the cyclin E expression after $48 \mathrm{~h}$ of treatment. Numeric data showing the proportion of cyclin E-positive cells in different cell-cycle phases are also listed.

In our previous study, we had purified a ß-type glucan, PCM3-II, from the mycelia of Poria cocos and its antitumor activity was partially elucidated on human leukemic HL-60 and mouse sarcoma S-180 cells (6). However, mechanisms for the antitumor effect of PCM3-II have not yet been investigated. The water-soluble PCM3-II was further characterized as being composed of $54.2 \% 1 \rightarrow 3$ linked and $45.8 \% 1 \rightarrow 4$ linked glucose residues (data not shown). To further increase our knowledge on the effects of PCM3-II on cancers of other histotypes, growth-inhibitory effects of PCM3-II were further investigated on the human breast carcinoma MCF-7 cells, which were found to be mediated at least via cell-cycle arrestment and apoptosis induction.

In general, cell-cycle transitions are controlled by cyclindependent kinases $(\mathrm{Cdks})$, which contain both regulatory (cyclin) and catalytic (Cdk) subunits. In mammalian cells, cyclin D-Cdk4/6 and cyclin E-Cdk2 are important for $\mathrm{G}_{1}$ progression and $\mathrm{G}_{1} / \mathrm{S}$ transition, respectively (11). Both cyclin D-Cdk4/6 and cyclin E-Cdk2 complexes have been shown to phosphorylate the retinoblastoma protein $(\mathrm{pRb})$; successive phosphorylations of $\mathrm{pRb}$ by both of these complexes may be required to inactivate the protein completely (15). The ability of $\mathrm{pRb}$ to bind to E2F-1 and hence repress the E2F-1dependent gene expression for $\mathrm{S}$ phase entry is well documented (16). Results from the bivariate cyclin/DNA flow cytometry illustrated that both cyclin D1 and cyclin E expressions were deregulated in the $\mathrm{MCF}-7$ cells, so that the proteins were found not only in $G_{1}$ and $S$ but also in other cell-cycle phases. This unscheduled pattern of cyclin expressions has also been observed in other cancers and has been suggested as a potential cause of tumor transformation $(17,18)$. Cyclin D1 is over-expressed in $30-40 \%$ of human breast cancers and is associated with poor prognosis in ER $\alpha$ positive cases (19). We determined in this study that both cyclin D1 and cyclin E expressions were depleted in the breast cancer cells after the PCM3-II treatment, suggesting that the $\mathrm{pRb}$ might remain bound to E2F-1 and the entry into $\mathrm{S}$ phase was thus prohibited. However, the signaling cascades 
(a)

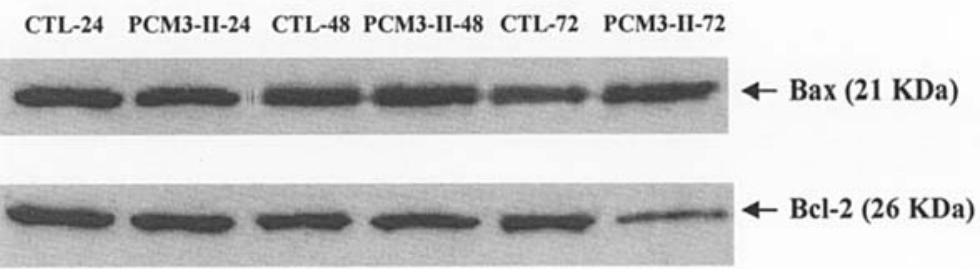

(b)

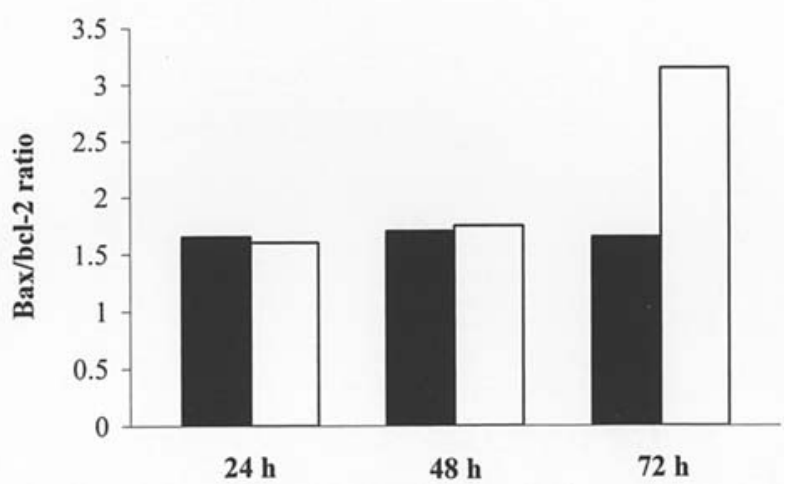

leading to the downregulation of cyclin expressions need further investigations.

Apoptosis is a form of cell death triggered during a variety of physiological conditions and is tightly regulated by a number of gene products that promote or block cell death at different stages. The PCM3-II-induced $\mathrm{G}_{1}$ arrest was followed by apoptosis after a longer period of treatment. The most extensively studied and perhaps most important are Bcl-2 family proteins (14). In mammals, Bcl-2 has at least 20 relatives, including 4 other antiapoptotic proteins: Bcl-xL, Bcl-w, A1 and Mcl1; and 2 groups of proteins that promote cell death: Bax and $\mathrm{BH} 3$-only families. Bax family, on the other hand, consists of Bax, Bak and Bok; and BH3-only family comprises Bid, Bim, Bik, Bad, Bmf, Hrk, Noxa and Puma $(14,20)$. These molecules either homodimerize or heterodimerize with molecule of opposing function. Bax may homodimerize so that apoptosis is promoted, or it may heterodimerize with $\mathrm{Bcl}-2$ or $\mathrm{Bcl}-\mathrm{xL}$ so that apoptosis is inhibited (21). The PCM3-II-induced apoptosis in the breast cancer cells was associated with downregulation of the antiapoptotic Bcl-2 expression; however, no significant change of the proapoptotic Bax expression was observed. The bax/bcl-2 ratio was found to be elevated at the time when most prominent apoptosis occurred. It has been shown previously that the $\mathrm{Bax} / \mathrm{Bcl}-2$ ratio determines the susceptibility of cells to the induced apoptosis (22). Bax associates in vivo with Bcl-2 protein and down-regulation of $\mathrm{Bcl}-2$ favors the formation of Bax homodimer that increases the rate of apoptosis and sensitivity of cells to apoptotic stimuli (23). Bax and a constitute mitochondrial protein, adenine nucleotide translocator, cooperate within the permeability transition pore complex to increase mitochondrial membrane permeability (24). The permeabilization results in the release of cytochrome $c$, apoptosis-inducing factor (AIF), and other pro-apoptotic molecules from mitochondria into the cytoplasm, which in turn
Figure 5. Effects of PCM3-II on the Bax and Bcl-2 expressions in MCF-7 cells determined by immunoblot analysis. (a) The breast cancer cells were incubated with $400-\mu \mathrm{g} / \mathrm{ml}$ PCM3-II for 24,48 and $72 \mathrm{~h}$ respectively, comparing to their corresponding time controls (CTL). The glucan induced depletion of the $\mathrm{Bcl}-2$ protein at $72 \mathrm{~h}$ of treatment, while there was no significant change of the Bax level with the different periods of incubation. (b) Intensity of the $\mathrm{Bax}$ and $\mathrm{Bcl}-2$ protein bands were measured with a densitometer; bax/bcl-2 ratio was calculated by dividing the densitometry reading of the bax band with that of the bcl-2 band. At $72 \mathrm{~h}$ of treatment, when the most prominent apoptosis was observed, $(\square)$ the glucan significantly elevated the ratio from ( $\mathbf{\square})$ the control level.

activate executioner caspases to orchestrate apoptosis (25). In conclusion, although the detailed mechanism for the antitumor activity of the $P$. cocos $\beta$-glucan still needs further investigation, results from this study provide preliminary insights into its mode of action and perspectives of its being developed as a novel and water-soluble antitumor agent.

\section{Acknowledgements}

The work described in this paper was supported by the Earmarked Research Grants Council (CUHK 4161/99M); the Lee Hysan Foundation, the United College, The Chinese University of Hong Kong; and the Area of Excellence on Plant and Fungal Biotechnology Project, the Hong Kong SAR Government.

\section{References}

1. Ukiya M, Akihisa T, Tokuda H, Hirano M, Oshikubo M, Nobukuni Y, Kimura Y, Tai T, Kondo S and Nishino H: Inhibition of tumor-promoting effects by poricoic acids $\mathrm{G}$ and $\mathrm{H}$ and other lanostane-type triterpenes and cytotoxic activity of poricoic acids A and G from Poria cocos. J Nat Prod 65: 462-465, 2002.

2. Mizushina Y, Akihisa T, Ukiya M, Murakami C, Kuriyama I, $\mathrm{Xu} \mathrm{X}$, Yoshida H and Sakaguchi K: A novel DNA topoisomerase inhibitor: dehydroebriconic acid, one of the lanostane-type triterpene acids from Poria cocos. Cancer Sci 95: 354-360, 2004.

3. Gapter L, Wang Z, Glinski J and Ng K-Y: Induction of apoptosis in prostate cancer cells by pachymic acid from Poria cocos. Biochem Biophys Res Commun 332: 1153-1161, 2005.

4. Zjawiony JK: Biologically active compounds from Aphyllophorales (polypore) fungi. J Nat Prod 67: 300-310, 2004.

5. Chen Y-Y and Chang H-M: Antiproliferative and differentiating effects of polysaccharide fraction from fu-ling (Poria cocos) on human leukemic U937 and HL-60 cells. Food Chem Toxicol 42: 759-769, 2004.

6. Jin Y, Zhang L, Zhang M, Chen L, Cheung PCK, Oi VEC and Lin Y: Antitumor activities of heteropolysaccharides of Poria cocos mycelia from different strains and culture media. Carbohydr Res 338: 1517-1521, 2003. 
7. Burdick AD, Davis JW II, Liu KJ, Hudson LG, Shi H, Monske ML and Burchiel SW: Benzo(a)pyrene quinones increase cell proliferation, generate reactive oxygen species, and transactivate the epidermal growth factor receptor in breast epithelial cells. Cancer Res 63: 7825-7833, 2003.

8. Weigelt B, Peterse JL and van't Veer LJ: Breast cancer metastasis: markers and models. Nat Rev Cancer 5: 591-602, 2005.

9. Dupont J and Roith DL: Insulin-like growth factor 1 and oestradiol promote cell proliferation of MCF-7 breast cancer cells: new insights into their synergistic effects. J Clin Pathol 54: 149-154, 2001.

10. Mosmann T: Rapid colorimetric assay for cellular growth and survival: application to proliferation and cytotoxicity assays. $\mathrm{J}$ Immunol Methods 63: 55-63, 1983.

11. Sherr CJ: The Pezcoller lecture: cancer cell cycles revisited. Cancer Res 60: 3689-3695, 2000.

12. Cummings J, Ward TH, Ranson M and Dive C: Apoptosis pathway-targeted drugs - from the bench to the clinic. Biochim Biophys Acta 1705: 53-66, 2004.

13. Darzynkiewicz Z and Bedner E: Analysis of apoptotic cells by flow and laser scanning cytometry. In: Methods in Enzymology. Volume 322. Apoptosis. Abelson JN and Simon M (eds). Academic Press, San Diego, CA, pp18-39, 2000.

14. Reed JC: Double identity for protein of Bcl-2 family. Nature 387: 773-778, 1997.

15. Harbour JW and Dean DC: Rb function in cell-cycle regulation and apoptosis. Nat Cell Biol 2: E65-E67, 2000.

16. Leone G, Sears R, Huang E, Rempel R, Nuckolls F, Park C-H, Giangrande P, Wu L, Saavedra HI, Field SJ, Thompson MA, Yang H, Fujiwara Y, Greenberg ME, Orkin S, Smith C and Nevins JR: Myc requires distinct E2F activities to induce $S$ phase and apoptosis. Mol Cell 8: 105-113, 2001.
17. Darzynkiewicz Z, Gong J, Juan G, Ardelt B and Traganos F: Cytometry of cyclin proteins. Cytometry 25: 1-13, 1996.

18. Paules RS, Levedakou EN, Wilson SJ, Innes CL, Rodes N, Tlsty TD, Galloway DA, Donehower LA, Tainsky MA and Kaufmann WK: Defective G2 checkpoint function in cells from individuals with familial cancer syndromes. Cancer Res 55: 1763-1773, 1995.

19. Kenny FS, Hui R, Musgrove EA, Gee JM, Blamey RW, Nicholson RI, Sutherland RL and Robertson JF: Overexpression of cyclin D1 messenger RNA predicts for poor prognosis in estrogen receptor-positive breast cancer. Clin Cancer Res 5: 2069-2076, 1999

20. Zamzami N: The mitochondrion in apoptosis: how Pandora's box opens. Nat Rev Mol Cell Biol 2: 67-71, 2001.

21. Oltvai $\mathrm{ZN}$ : Bcl-2 heterodimerizes in vivo with a conserved homolog, bax that accelerates programmed cell death. Cell 74: 609-619, 1993.

22. Raisova M: The Bax/Bcl-2 ratio determines the susceptibility of human melanoma cells to CD95/Fas-mediated apoptosis. J Invest Dermatol 117: 333-340, 2001.

23. Salomons GS: The baxa:bcl-2 ratio modulates the response to dexamethasone in leukaemic cells and is highly variable in childhood acute leukemia. Int J Cancer 71: 959-965, 1997.

24. Marzo I: Bax and adenine nucleotide translocator cooperate in the mitochondrial control of apoptosis. Science 281: 2027-2031, 1998.

25. Kroemer G: Mitochondrial control of cell death. Nat Med 6: 513-519, 2000. 